\title{
ANALISIS MISKONSEPSI SUBMIKROSKOPIK KONSEP LARUTAN PADA CALON GURU KIMIA
}

\author{
Muhamad Imaduddin \\ IAIN Kudus \\ e-mail: imad@stainkudus.ac.id
}

\begin{abstract}
Abstrak
Penelitian ini bertujuan untuk menganalisis miskonspsi submikroskopik tentang konsep larutan pada calon guru kimia. Cakupan konsep berkenaan dengan komponen larutan, konsentrasi, serta sifat asam basa pada larutan berair. Penelitian ini melibatkan 36 calon guru kimia tahun pertama di Universitas Islam Negeri Walisongo Semarang, Jawa Tengah. Metode pengumpulan data menggunakan Tes Analisis Miskonsepsi Submikroskopik (TAMS) serta wawancara terstrukstur. Teknik analisis TAMS mengunakan pengkategorian interpretasi, sedangkan analisis wawancara dilakukan melalui transkripsi, reduksi respon, serta pengkodean sesuai dengan miskonsepsi yang terjadi pada aspek makroskopik, submikroskopik, dan simbolik merujuk pada konsep kimia larutan. Hasil menunjukkan masih banyak partisipan calon guru yang mengalami kesulitan untuk menghubungkan konsep level makroskopik (larutan) dengan level submikroskopik (pemodelan larutan), maupun kaitannya dengan level simbolik yaitu konsentrasi atau molaritas larutan. Hanya satu calon guru yang mampu merepresentasikan jumlah partikel dan penyusunan partikel dalam gambar dengan tepat secara keseluruhan, serta dapat mengkonfirmasi hasilnya. Kondisi tidak terhubungnya level representasi makroskopik, submikroskopik, dan simbolik pada calon guru dikarenakan pemahaman konsep pada level sekolah dan perkuliahan sebelumnya belum komprehensif. Dengan demikian, diperlukan perbaikan proses belajar dan mengajarkan kimia bagi calon guru agar tidak terjadi miskonsepsi lanjutan pada siswa dalam memahami konten kimia di masa mendatang.
\end{abstract}

Kata Kunci: Miskonsepsi; Calon guru Kimia; Submikroskopik; Larutan.

\begin{abstract}
This study aimed to analyze submicroscopic misconceptions on the concept of solution of pre-service chemistery teachers. The scope of the concept dealt with the components of the solution, concentration, and the nature of acid-base in the aqueous solution. This study had involving 36 first-year pre-service chemistry teachers at Walisongo State Islamic University Semarang, Central Java. The method of collecting data used the Submicroscopic Misconception Analysis Test (SMAT) and structured interviews. The SMAT analysis technique used categorization of interpretations, while the interview analysis is done through transcription, response reduction, and coding according to the misconceptions that occur in the macroscopic, submicroscopic, and symbolic aspects referring to the chemical concept of solution. The results shows that many pre-service teacher participants find the difficulty deal with the concept of macroscopic (solution) level with submicroscopic level (solution modeling), as well as its relation to the symbolic level of solution concentration or molarity. Only one pre-service teacher was able to represent the number of particles, arrangement of particles in the image correctly and confirm the results. The condition of pre-service teachers' disconnected macroscopic, submicroscopic, and symbolic levels of representation was the result of their misconception on those concepts at the school level and previous incomprehensive lectures. Thus, it is necessary to improve
\end{abstract}


the teaching and learning process toward pre-service chemistry teachers so there will be no further misconception of the materials in the future.

Keywords: Misconception, Pre-service chemistry teacher, Submicroscopic, Solution.

\section{PENDAHULUAN}

Sains, terutama kimia, sering kali dianggap oleh para guru, peneliti, dan pendidik sebagai pelajaran yang sulit bagi siswa. Beberapa literatur juga mengindikasikan kesulitankesulitan yang mungkin terjadi dalam mempelajari kimia. Kesulitan-kesulitan tersebut menjadikan peserta didik tidak menguasi materi kimia sepenuhnya (Sirhan, 2007). Salah satu alasan penting kesulitan siswa dalam memahami kimia erat kaitannya dengan representasi multipel level (multiple levels of representation) yang digunakan dalam menggambarkan dan menjelaskan fenomena-fenomena kimia (Chandrasegaran, Treagust, \& Mocerino, 2007; Eilks, Moellering, \& Valanides, 2007; Johnstone, 2000a, 2000b; Tasker \& Dalton, 2006).

Penguasaan peserta didik terhadap konsep kimia seharusnya dapat ditunjukkan oleh kemampuan mentransfer dan menghubungkan antara tiga level representasi kimia yang terdiri dari level makroskopik, submikroskopik, dan simbolik (Farida, 2012; Hinton \& Nakhleh, 1999; Johnstone, 2000a, 2000b; Talanquer, 2011; Treagust \& Chandrasegaran, 2009; Tuysuz, Ekiz, Uzuntiryaki, Tarkin, \& Kutucu, 2011). Representasi makroskopik menggambarkan sifat penting dari fenomena-fenomena nyata dan dapat dilihat melalui pengalaman-pengalaman sehari-hari. Sebagai contoh bagi pebelajar (learner) adalah ketika mengamati perubahan sifat dari materi semisal perubahan warna, buih, dan pembentukan gas serta pengendapan dalam reaksi kimia. Adapun representasi submikroskopik (atau molekuler) memberikan penjelasan atas level partikulat. Level ini bersifat nyata dan terdiri atas level-level partikulat yang digunakan untuk menggambarkan pergerakan-pergerakan elektron, molekul, partikel dan atom. Materi dideskripsikan sebagai susunan atom-atom, molekul-molekul, maupun ion-ion. Representasi simbolik (atau ikonik) melibatkan penggunaan simbol-simbol kimia, rumus dan persamaan, gambar struktur molekul, diagram, representasi piktorial (gambar), aljabar, maupun bentuk-bentuk komputasional dari representasi submikroskopik (Chandrasegaran et al., 2007; Chittleborough \& Treagust, 2007; Devetak, 2007; Devetak, Urbančič, K.S.W., Krnel, \& Glažar, 2004; Tasker \& Dalton, 2006; Wu, Krajcik, \& Soloway, 2001).

Belajar konsep pada dasarnya adalah meletakkan berbagai macam hal ke dalam golongan-golongan dan setelah itu mampu mengenali anggota-anggota golongan itu (Arends, 2012). Abstraksi berarti proses pemusatan perhatian seseorang pada situasi tertentu dan mengambil elemen-elemen tertentu, serta mengabaikan elemen-elemen yang lain. Oleh karena itu, untuk dapat menguasai konsep peserta didik harus mampu 
membedakan antara satu dengan peristiwa yang lain, sehingga dapat menggolongkan dunia sekitarnya menurut konsep itu, misalnya warna, bentuk, jumlah, dan sebagainya.

Ahli konstrutivis sependapat bahwa pengetahuan tidak dapat secara sederhana dipindahkan dari pendidik ke peserta didik. Peserta didik harus secara aktif mengkonstruksi pengetahuan mereka dari informasi baru dan pengalaman dan pengetahuan baru yang mereka dapatkan. Peserta didik menggunakan pengetahuan mereka sebagai dasar untuk mengevaluasi informasi baru. Bila informasi baru konsisten dengan pengetahuan yang sudah ada, informasi baru ini akan diasimilasi, tetapi bila berbeda sama sekali (kontradiktif) akan dilakukan akomodasi pengetahuan agar sesuai dengan informasi baru. Konstruktivis juga memperhatikan konteks dari pengetahuan yang dibangun (Sanger \& Greenbowe, 1997). Dalam proses menyampaikan informasi baru ke dalam struktur kognitif, peserta didik sering kali mengalami kesulitan, bahkan kegagalan. Hal inilah yang kemudian menjadi timbulnya miskonsepsi pada kognitif peserta didik.

Berbagai temuan penelitian telah menyatakan kesulitan pada konsep-konsep yang berkaitan dengan konsep tentang asam dan basa (Çetingül \& Geban, 2005; Chaiyapha, Chayajarus, \& Chairam, 2011; Drechsler \& Schmidt, 2005; Metin, 2011; Muchtar \& Harizal, 2012; Rahayu, 2011; Sheppard, 2006) serta konsep pH (Watters \& Watters, 2006). Konsep-konsep tersebut berhubungan erat dengan pemahaman secara mikroskopik pada konsep larutan, serta konsentrasi larutan. Oleh karena itu, penting untuk mencoba mengungkap bagaimana pemahaman konsep dan miskonsepsi yang terjadi pada peserta didik. Penelitian ini menjadi pijakan awal untuk mengembangakan pembelajaran konsep kimia yang tepat dengan menekankan pada keterkaitan pada ketiga aspek representasi kimia. Deskripsi miskonsepsi yang terjadi dapat digunakan untuk menentukan strategi pembelajaran yang tepat bagi para calon guru, sehingga miskonsepsi yang terjadi dapat diperbaiki dan tidak dibawa oleh para calon guru ketika menjadi guru di masa mendatang. Pada penelitian ini diungkap miskonsepsi yang terjadi pada peserta didik yang merupakan calon guru kimia dengan diawali pada pemahaman konsep fisik larutan, serta ditindaklanjuti melalui kegiatan umpan balik untuk melihat seberapa jauh pemahaman konsep pada kesetimbangan yang terjadi pada larutan mencakup kesetimbangan yang terjadi pada asam basa, maupun kesetimbangan yang terjadi pada proses kelarutan.

\section{METODE}

Penelitian ini merupakan penelitian deskriptif untuk mengidentifikasi miskonsepsi yang terjadi pada level submikroskopik. Survei dilakukan terhadap 36 calon guru kimia tahun pertama di Universitas Islam Negeri Walisongo Semarang. Instrumen pengumpulan data dengan menggunakan Tes Analisis Miskonsepsi Submikroskopik (TAMS) yang terdiri dari empat buti soal tes sebagaimana diperlihatkan pada Gambar 1. 
Larutan encer dari senyawa yang gama ada dalam gelas beaker A dan gelas beaker B. Volume Larutan menunjukkcan bahwa:

a) Larutan A lebih pekat daripada larutan B.

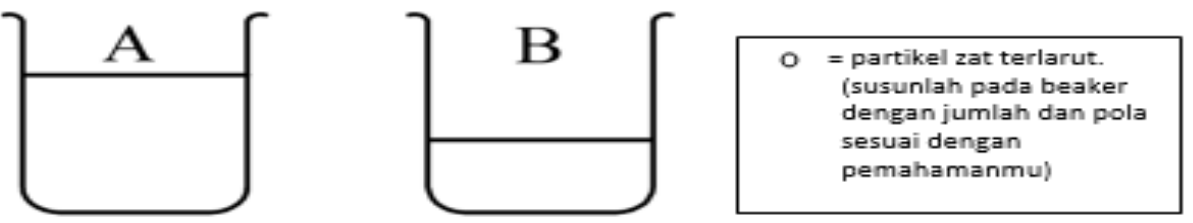

b) Kedua larutan mempunyai kongentrasi yang sama.

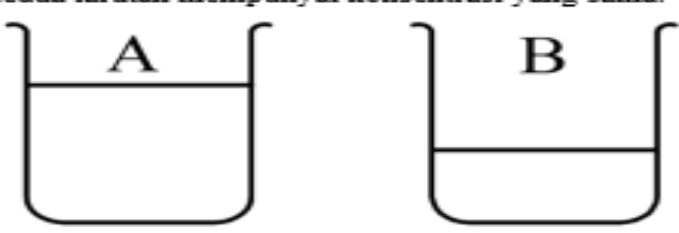

c) Konsentrasi larutan A besarnya $\frac{1}{3}$ kali konsentrasi larutan B.

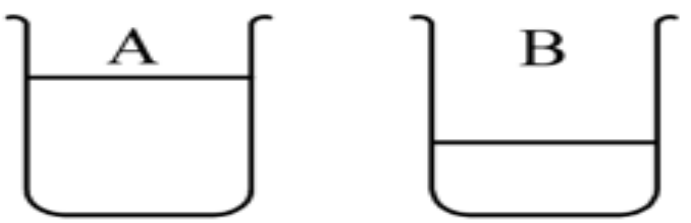

d) Konsentrasi larutan B besarnya 3 kali konsentrasi larutan A.

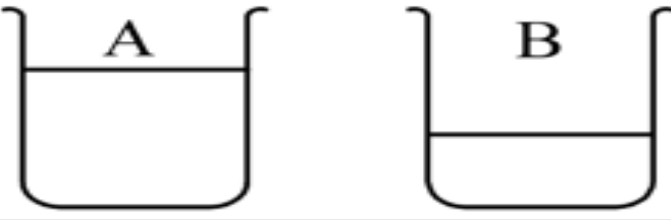

Gambar 1. Tes Analisis Miskonsepsi Submikroskopik (TAMS)

TAMS diadaptasi dari Devetak et al. (2004) dengan pengembangan pada kontennya. Tes tersebut digunakan untuk mengetahui bagaimana calon guru menggambarkan partikel zat terlarut dengan konsentrasi larutan tertentu. Selanjutnya, dilakukan pula pengumpulan data melalui wawancara yang dibagi menjadi beberapa sesi pertanyaan yang berisi konten tentang larutan, kesetimbangan dalam larutan asam dan basa, serta kesetimbangan kelarutan. Analisis wawancara dilakukan melalui transkripsi, reduksi respon, serta pengkodean sesuai dengan miskonsepsi yang terjadi pada aspek makroskopik, submikroskopik, dan simbolik merujuk pada konsep kimia larutan.

\section{HASIL DAN PEMBAHASAN}

Penguasaan konsep didasarkan pada kemampuan calon guru untuk menghubungkan level-level representasi kimia baik makroskopik, submikroskopik, dan simbolik. Hasil survei menggunakan TAMS menunjukkan bahwa peserta didik menggambarkan zat terlarut pada beberapa kondisi seperti yang diuraikan pada Tabel 1 . Survei tersebut menunjukkan bagaimana peserta didik menyusun gambar partikel zat terlarut, serta susunan partikelnya pada pelarut air. 
Tabel 1. Hasil Interpretasi Tes Analisis Miskonsepsi Submikroskopik

\begin{tabular}{|c|c|c|c|c|c|}
\hline \multirow[t]{2}{*}{ No } & \multirow[t]{2}{*}{ Model yang digambarkan } & \multicolumn{4}{|c|}{ Jumlah mahasiswa yang menjawab } \\
\hline & & Soal I & Soal II & Soal III & Soal IV \\
\hline 1 & Jumlah partikel dan susunannya tepat & 6 & 1 & 1 & 1 \\
\hline 2 & $\begin{array}{l}\text { Jumlah partikel tepat, tetapi susunannya } \\
\text { tidak tepat }\end{array}$ & 24 & 15 & 5 & 6 \\
\hline 3 & $\begin{array}{l}\text { Jumlah partikel tidak tepat, tetapi } \\
\text { susunannya tepat }\end{array}$ & 2 & 4 & 4 & 4 \\
\hline 4 & Jumlah dan susunan partikel tidak tepat & 4 & 16 & 26 & 25 \\
\hline & Total & 36 & 36 & 36 & 36 \\
\hline
\end{tabular}

Keterangan:

Larutan encer dari senyawa yang sama ada dalam gelas beaker A dan gelas beaker B. Volume Larutan A dua kali lebih besar dari volum larutan B. Peserta didik diminta melengkapi gambar dengan partikel zat terlarut untuk menunjukkan bahwa:

Soal I : Larutan A lebih pekat daripada larutan B.

Soal II : Kedua larutan mempunyai konsentrasi yang sama.

Soal III : Konsentrasi larutan A besarnya $\frac{1}{3}$ kali konsentrasi larutan B Soal IV : Konsentrasi larutan B besarnya 3 kali konsentrasi larutan A.

Berdasarkan Tabel 1. hanya terdapat satu calon guru yang mampu merepresentasikan jumlah partikel dan penyusunan partikel dalam gambar dengan tepat secara keseluruhan, serta dapat mengkonfirmasi hasilnya. Masih banyak calon guru yang mengalami kesulitan untuk menghubungkan konsep level makroskopik (larutan) dengan level submikroskopik (pemodelan larutan), maupun kaitannya dengan level simbolik ( $\mathrm{M}=$ $\left.\frac{\mathrm{Mol}}{\text { Volume(L) }}\right)$. Di dalam menggambarkan representasi model larutan, peserta didik cenderung tidak memperhatikan susunan dari partikel-partikel zat terlarut dalam larutan. Ada kecenderungan hanya memperhatikan jumlah dari komponen zat terlarut. Berdasarkan hal ini, dapat diketahui bahwa peserta didik belum terbiasa menggunakan kemampuan memodelkan (modelling ability). Modelling ability ini berhubungan dengan representasi level makroskopik dan submikroskopik suatu zat (Chittleborough \& Treagust, 2007). Contoh jawaban dari calon guru kimia diperlihatkan pada Gambar 2.

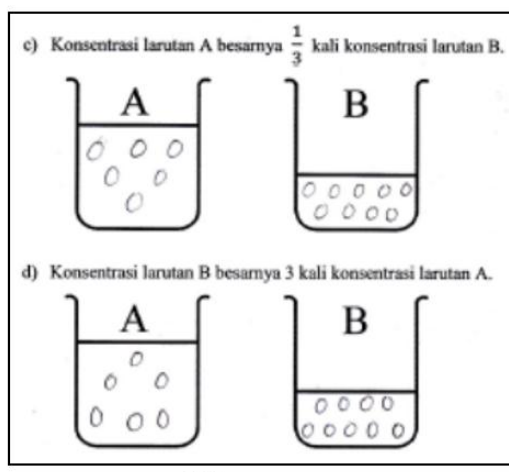

(a)

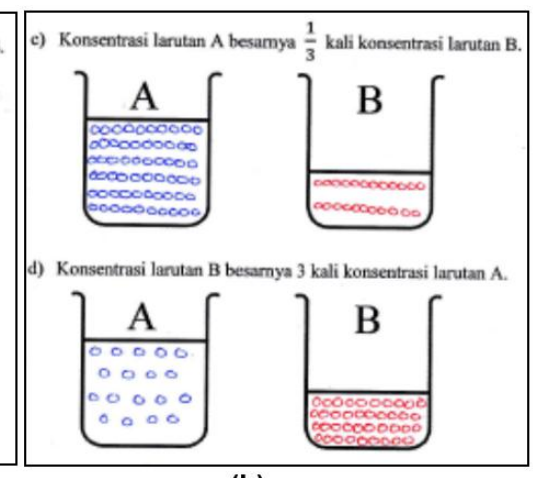

(b)

Gambar 2. Contoh Jawaban Calon Guru Kimia 
Keterangan: (a) jawaban dengan jumlah partikel dan susunannya tepat; (b) Jumlah partikel dan susunannya tidak tepat.

Berdasarkan Tabel 1. dapat diketahui pula bahwa kemampuan mendeskripsikan, mengidentifikasi kalimat-kalimat pertanyaan belum terlihat baik. Hal ini diperlihatkan dari kemampuan untuk menjawab soal ke III dan ke IV. Soal III yaitu "Konsentrasi larutan A besarnya $\frac{1}{3}$ kali konsentrasi larutan B" dan soal IV yaitu "Konsentrasi larutan B besarnya 3 kali konsentrasi larutan A". Pada dasarnya, kedua soal tersebut memiliki makna yang sama. Meskipun demikian, banyak peserta didik yang menggambarkan susunan dan jumlah partikel yang berbeda sehingga menunjukkan interpretasi yang berbeda pada kedua pernyataaan tersebut.

Berdasarkan wawancara dengan beberapa peserta didik terhadap hasil tes, diketahui bahwa peserta didik cenderung mudah dipengaruhi oleh gambar pola susunan partikel yang mereka lihat dari teman-temannya. Mereka cenderung bertindak tanpa memikirkan ulang dan tidak memunculkan ide-ide sendiri. Calon guru kimia hanya mendapatkan pengetahuan tentang konsep larutan melalui menghafal tanpa memahami konsepnya (Lin, Chiu, \& Liang, 2004). Pada dasarnya konsep-konsep kimia ini akan mudah terungkap dengan memahami representasi mikroskopis (Smith \& Metz, 1996).

Penggunaan representasi dengan berbagai cara atau mode representasi untuk merepresentasikan suatu fenomena disebut multipel representasi. Waldrip, Prain, \& Carolan (2006) mendefinisikan multipel representasi sebagai praktik merepresentasikan kembali (re-representing) konsep yang sama melalui berbagai bentuk, yang mencakup mode-mode representasi deskriptif (verbal, grafik, tabel), eksperimental, matematis, figuratif (piktorial, analogi, dan metafora), kinestetik, visual, dan/atau mode aksionaloperasional. Johnstone (2000b) membangun hubungan kuat antara level "descriptive and functional" dengan level macrochemistry, antara level "representational" dengan bahasa simbolik, serta antara level "explanatory" dengan teori partikulat dan model materi (pada awalnya merujuk pada microchemistry, dan pada akhirnya menjadi submicrochemistry).

Peserta didik sering belajar bagaimana untuk memecahkan masalah matematika tanpa memahami kimia secara menyeluruh pada ketiga level representasi kimia. Mereka menghafal definisi kimia dan menggunakan istilah kimia tanpa pemahaman yang benar. Hal ini bisa mengakibatkan miskonsepsi. Miskonsepsi tentang konsep fisis larutan, asam dan basa, kekuatan asam, disosiasi, molekul unsur diatomik, ikatan, dan larutan dapat mengganggu pembelajaran selanjutnya dan dapat bertahan melampaui tingkat sarjana (Smith \& Metz, 1996). Apabila seorang pendidik peduli terhadap miskonsepsi yang terjadi pada peserta didiknya, niscaya miskonsepsi tersebut akan lebih mudah untuk dihindari dan dihilangkan (Schmidt \& Chemie, 1995). 
Pada dasarnya penguasaan konsep merupakan karakteristik secara individual. Oleh karena itu, diperlukan untuk melihat peserta didik sebagai individu dan menggunakan mereka sebagai studi kasus (case study) dalam suatu populasi (Chittleborough \& Treagust, 2007; Cohen, Manion, \& Morrison, 2007). Case study ini dilakukan dengan menghadirkan subyek uji coba sebagai narasumber wawancara. Adapun data deskriptif dari narasumber dapat dilihat pada Tabel 2. Hasil yang diperoleh digunakan sebagai dasar untuk memetakan miskonsepsi yang sering kali muncul pada konsep larutan asam basa, kesetimbangan asam basa dalam larutan, serta kesetimbangan kelarutan dan hasil kali kelarutan. Hal ini dilakukan karena mengidentifikasi miskonsepsi peserta didik pada dasarnya adalah langkah pertama untuk mencegah miskonsepsi dalam kimia (Muchtar \& Harizal, 2012).

Tabel 2. Data Deskriptif Narasumber

\begin{tabular}{ccc}
\hline Kode & $\begin{array}{c}\text { Usia } \\
\text { (tahun) }\end{array}$ & Pengalaman dengan materi Kimia \\
\hline N1 & 17 & MA dan Kimia Dasar 1 \\
\hline N2 & 19 & MTs (mapel IPA), MA dan Kimia Dasar 1 \\
\hline N3 & 19 & SMP (mapel IPA), SMA, dan Kimia Dasar 1 \\
\hline N4 & 19 & MTs (mapel IPA), MA, dan Kimia Dasar 1 \\
\hline N5 & 19 & SMP (mapel IPA), MA, dan Kimia Dasar 1 \\
\hline N6 & 20 & SMP (mapel IPA), SMA, dan Kimia Dasar 1 \\
\hline N7 & 19 & SMP (mapel IPA), MA, dan Kimia Dasar 1 \\
\hline N8 & 19 & SMA dan Kimia Dasar 1 \\
\hline N9 & 20 & MA dan Kimia Dasar 1 \\
\hline
\end{tabular}

Jumlah narasumber yang bersedia untuk diwawancarai sebanyak 13 calon guru kimia. Meskipun demikian, hanya hasil wawancara sembilan narasumber yang dianalisis karena mempertimbangkan kejenuhan data dan kasus-kasus yang menarik pada hasil wawancara. Wawancara dibagi menjadi beberapa sesi pertanyaan. Wawancara lanjutan dilanjutkan untuk melihat pemahaman keterkaitan ketiga level representasi secara lebih mendalam pada konsep larutan. Konsep larutan mencakup pada penguasaan konsep kesetimbangan larutan pada larutan asam basa dan kesetimbangan kelarutan. Hasil wawacara selanjutnya ditranskripsi, serta dilakukan reduksi data, pengkodean, dan pengelompokan pada komponen dimensi level representasi terkait dengan temuan miskonsepsi. Hasil wawancara kemudian dianalisis dan dipetakan ke dalam tabel kerangka miskonsepsi dan dihubungkan dengan penelitian-penelitian yang telah ada sebagaimana ditunjukkan pada Tabel 3. 
Tabel 3. Pemetaan Miskonsepsi Peserta Didik

\begin{tabular}{|c|c|c|c|}
\hline No & Miskonsepsi yang Muncul pada Peserta Didik & $\begin{array}{l}\text { Dimensi } \\
\text { Level } \\
\text { Representasi }\end{array}$ & $\begin{array}{l}\text { Temuan yang } \\
\text { Relevan }\end{array}$ \\
\hline 1 & $\begin{array}{l}\text { Tidak familiar dengan teori-teori asam basa Bronsted-Lowry dan } \\
\text { terutama asam basa Lewis. Submiskonsepsi ini mungkin akan } \\
\text { mengarah pada penggunaan satu teori asam-basa untuk } \\
\text { menjelaskan keseluruhan reaksi asam dan basa. }\end{array}$ & Mak $\rightarrow$ Sim & $\begin{array}{c}\text { Muchtar \& } \\
\text { Harizal (2012) }\end{array}$ \\
\hline 2 & $\begin{array}{l}\text { Larutan asam pasti menghantarkan listrik sedangkan larutan } \\
\text { basa tidak menghantarkan listrik. }\end{array}$ & Mak $\rightarrow$ Mik & $\begin{array}{c}\text { Çetingül \& } \\
\text { Geban (2005) }\end{array}$ \\
\hline 3 & $\begin{array}{l}\mathrm{CH}_{3} \mathrm{COOH} \text { sebagai basa karena adanya } \mathrm{OH}^{-} \text {. Narasumber } \\
\text { memperhatikan bahwa ada tidaknya " } \mathrm{H} \text { " dan "OH" di dalam } \\
\text { rumus kimia sebagai kriteria untuk menentukan sifat asam dan } \\
\text { basa }\end{array}$ & Sim $\rightarrow$ Mak & $\begin{array}{l}\text { Lin (2004); } \\
\text { Çetingül \& } \\
\text { Geban (2005); } \\
\text { Rahayu (2011) }\end{array}$ \\
\hline 4 & $\begin{array}{l}\text { lon } \mathrm{OH}^{-} \text {tidak ada di dalam larutan asam. Hanya terdapat } \mathrm{H}^{+} \\
\text {dalam larutan asam. Di dalam larutan basa hanya terdapat ion } \\
\mathrm{OH}^{-} \text {. }\end{array}$ & Sim $\rightarrow$ Mik & \\
\hline 5 & $\begin{array}{l}\text { Asam kuat akan memiliki pH yang rendah sedangkan asam } \\
\text { lemah akan memiliki pH yang mendekati basa. Narasumber } \\
\text { belum menyadari bahwa digolongkan asam kuat karena sifat } \\
\text { ionisasinya yang hampir sempurna, sedangkan asam lemah } \\
\text { karena sebagian kecil molekulnya yang mengalami ionisasi. }\end{array}$ & Mik $\rightarrow$ Mak & $\begin{array}{c}\text { Çetingül \& } \\
\text { Geban (2005) }\end{array}$ \\
\hline 6 & $\begin{array}{l}\mathrm{B}(\mathrm{OH})_{3}(\mathrm{aq})+\mathrm{H}_{2} \mathrm{O} \rightleftharpoons \mathrm{B}(\mathrm{OH})_{4}(\mathrm{aq})+\mathrm{H}^{+}(\mathrm{aq}) \text {. Dalam reaksi } \\
\text { tersebut, } \mathrm{B}(\mathrm{OH})_{3}(\mathrm{aq}) \text { dianggap sebagai basa karena } \mathrm{B}(\mathrm{OH})_{3} \\
\text { mengandung OH}\end{array}$ & $\begin{array}{l}\text { Sim } \rightarrow \text { Mik } \\
\text { Sim } \rightarrow \text { Mak }\end{array}$ & \\
\hline 7 & $\begin{array}{l}\text { Asam memiliki nilai } \mathrm{pH} \text { tetapi tidak memiliki nilai } \mathrm{pOH} \text {. } \mathrm{pOH} \\
\text { hanya untuk basa. }\end{array}$ & $\begin{array}{l}\text { Mak } \rightarrow \text { Sim } \\
\text { Sim } \rightarrow \text { Mik }\end{array}$ & \\
\hline 8 & $\begin{array}{l}\text { Konsentrasi ion hidrogen hanya dipengaruhi jumlah hidrogen } \\
\text { (atom H) pada rumus kimia. Kriteria asam kuat dan asam lemah } \\
\text { (pada konsentrasi sama dengan jumlah atom H pada rumus } \\
\text { kimia sama) tidak mempengaruhi konsentrasi ion hidrogen yang } \\
\text { ada. }\end{array}$ & Mik $\rightarrow$ Sim & Chiu (2005) \\
\hline 9 & $\begin{array}{l}\text { Jika konsentrasi } \mathrm{HCl}=10^{-8} \mathrm{M} \text { maka } \mathrm{pH} \mathrm{HCl}=8 \text { dan artinya } \mathrm{HCl} \\
\text { itu basa. } \mathrm{HCl} \text { itu asam bukan basa. Jadi, Tidak ada larutan } \mathrm{HCl} \\
\text { dengan konsentrasi } 10^{-8} \mathrm{M} \text {. }\end{array}$ & $\begin{array}{l}\text { Mak } \rightarrow \text { Sim } \\
\text { Sim } \rightarrow \text { Mik }\end{array}$ & \\
\hline 10 & $\begin{array}{l}\mathrm{HCl} \text { dengan konsentrasi } 10^{-8} \mathrm{M} \text { bersifat basa karena } \mathrm{pH}=8 \text {. } \\
\text { (Tidak adanya kontribusi ion } \mathrm{H}^{+} \text {dari air). }\end{array}$ & $\begin{array}{l}\text { Mak } \rightarrow \text { Sim } \\
\text { Sim } \rightarrow \text { Mik }\end{array}$ & $\begin{array}{c}\text { Watters \& } \\
\text { Watters (2006) }\end{array}$ \\
\hline 11 & Kesalahan dalam interpretasi kurva Titrasi Asam dan Basa & $\begin{array}{l}\text { Sim } \rightarrow \text { Mik } \\
\text { Sim } \rightarrow \text { Mak }\end{array}$ & Sheppard (2006) \\
\hline 12 & $\begin{array}{l}\text { Tidak ada kontribusi dari basa konjugasi pada larutan } \\
\text { penyangga asam, dan sebaliknya tidak ada kontribusi asam } \\
\text { konjugasi pada larutan penyangga basa. } \\
\text { Keterangan: tidak familiarnya penggunaan rumus penyangga } \\
{\left[\mathrm{H}^{+}\right]=\mathrm{Ka} \times \frac{\left[\mathrm{CH}_{2} \mathrm{COOH}\right]}{\left[\mathrm{CH}_{2} \mathrm{COO}\right]} \text {; untuk menentukan }\left[\mathrm{H}^{+}\right] \text {pada larutan }} \\
\text { penyangga yang komponen larutan asam lemah } \mathrm{CH}_{3} \mathrm{COOH} \text {. }\end{array}$ & $\begin{array}{l}\text { Sim } \rightarrow \text { Mak } \\
\text { Sim } \rightarrow \text { Mik }\end{array}$ & \\
\hline 13 & $\begin{array}{l}\text { Kesalahan dalam memahami sumber dan arah tranfer atau } \\
\text { perpindahan proton. } \\
\text { Keterangan: Reaksi yang ditanyakan }\end{array}$ & Sim $\rightarrow$ Mik & \\
\hline & $\mathrm{CH}_{3} \mathrm{COOH}(\mathrm{aq})+\mathrm{H}_{2} \mathrm{O}(\mathrm{l}) \rightleftharpoons \mathrm{H}_{3} \mathrm{O}^{+}(\mathrm{aq})$ & & \\
\hline
\end{tabular}

14 Kesalahpahaman dalam memahami konsep larutan jenuh. (Jika Mak $\rightarrow$ Mik Krause \& Tasooji ke dalam larutan yang jenuh di tambah zat terlarut yang sama, (2007) yang terjadi adalah konsentrasi zat terlarut dalam larutan berubah)

Keterangan: Mak = level makroskopik; Mik = level submikroskopik; Sim = level simbolik 
Hasil analisis wawancara menunjukkan representasi makroskopik semisal adanya larutan $\mathrm{HCl}, \mathrm{NaOH}$, serta wujud larutan elektrolit dan elektrolit belum dapat sepenuhnya dikaitkan dengan aspek submikroskopik semisal kondisi submikroskopik yang terjadi pada asam kuat dan asam lemah. Calon guru berasumsi perbedaan pada konsep konsentrasi dan $\mathrm{pH}$ yang ada pada larutan untuk menyatakan kuat tidaknya suatu jenis larutan asam padahal seharusnya calon guru meninjau konsep derajat disosiasi yang ada pada larutan. Penjelasan ini dapat dilihat dari pernyataan yang menunjukkan bahwa $\mathrm{HCl} 0,1 \mathrm{M}$ termasuk asam kuat karena $\mathrm{pH}$ yang dimiliki adalah 1 , sedangkan $\mathrm{HCl} 10^{-6} \mathrm{M}$ dengan $\mathrm{pH}=6$ merupakan asam lemah. Lebih lanjut, dinyatkan pula bahwa $\mathrm{HCl}$ dengan konsentrasi $10^{-8}$ $\mathrm{M}$ bersifat basa karena $\mathrm{pH}=8$. Calon guru belum memperhatikan adanya kontribusi ion $\mathrm{H}^{+}$ dari air. Didasarkan pada hal ini, calon guru menunjukkan belum mampunya mengaitkan aspek makroskopik, dengan representasi simbolik $\mathrm{pH}$, serta kondisi submikroskopik adanya kontribusi dari komponen pelarut air pada penentuan $\mathrm{pH}$ suatu larutan encer $(\mathrm{HCl}$ $\left.10^{-8} \mathrm{M}\right)$. Kasus-kasus yang diperoleh pada analisis lanjutan hasil representasi TAMS menunjukkan kondisi pemahaman calon guru yang disajikan pada Tabel 3. Berdasarkan hasil TAMS serta analisis hasil wawancara dapat diperoleh informasi tentang bagaimana kemampuan calon guru kimia tahun pertama dalam menghubungkan level-level representasi kimia. Pola yang diperoleh dapat dilihat pada Gambar 3.

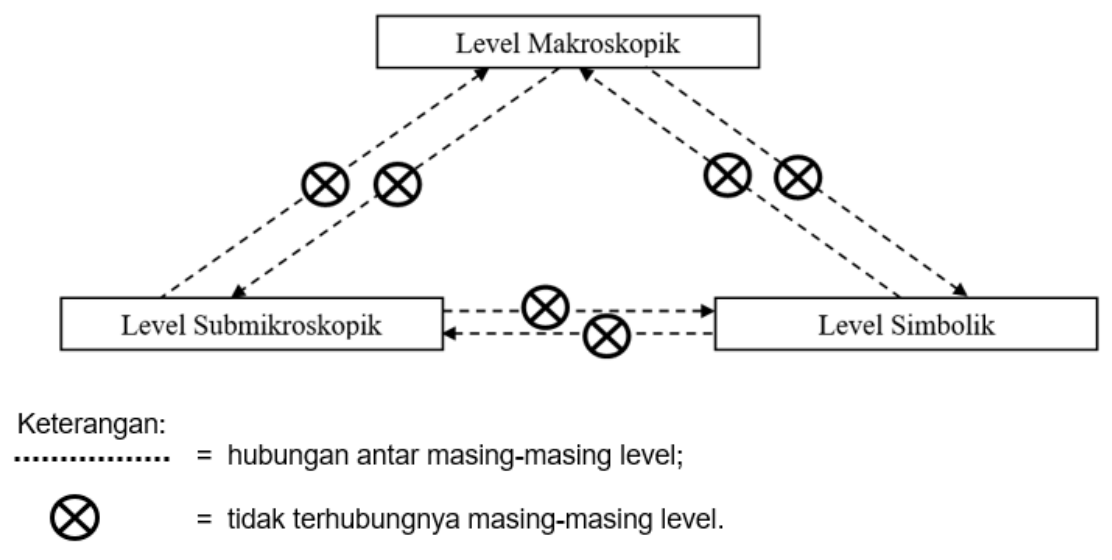

Gambar 3. Pola Penguasaan Konsep Mahasiswa Calon Guru Kimia pada Tahun Pertama

Gambar 3. menunjukkan bahwa calon guru belum dapat menghubungakan ketiga level representasi kimia pada kajian penelitian ini. Berdasarkan hasil wawancara, sering ditemukan bahwa pendidik calon guru pada jenjang sebelumnya sering hanya menilai kemampuan mereka dalam menyelesaikan perhitungan matematis atau kemampuan reprsentasi simbolik saja. Pendidik tidak memberikan penekanan pada penguasaan konsep dengan melatihkan keterampilan mendeskripsikan proses submikroskopik yang terjadi pada larutan. Hal ini sejalan dengan kajian yang dilakukan oleh Lee (1999). Oleh 
karena itu, peserta didik sering berpikir bahwa kimia adalah ilmu yang hanya mempelajari simbol-simbol unsur, rumus senyawa dan persamaan kimia. Peserta didik tidak memahami sifat partikel maupun menggambarkan proses dinamis (Mulford \& Robinson, 2002). Kondisi pembelajaran kimia yang sebelumnya diperoleh oleh para calon guru kimia tahun pertama mengindikasikan belum adanya kematangan konsep kimia yang diperolehnya pada level sebelumnya atau kimia pada level sekolah. Dengan demikian, pada program penyiapan calon guru kimia, diperlukan perubahan paradigma untuk memberikan penguasaan kimia yang tidak sebatas pada hafalan dan perhitungan matematis saja. Penguasaan konsep pada ketiga level representasi kimia akan bermanfaat dalam mengkomunikasikan kimia kepada peserta didik para calon guru kimia di masa mendatang.

\section{SIMPULAN}

Kajian analisis miskonsepsi submikroskopik menunjukkan bahwa masih banyak calon guru kimia tahun pertama yang mengalami kesulitan untuk menghubungkan konsep level makroskopik (larutan) dengan level submikroskopik (pemodelan larutan), maupun kaitannya dengan level simbolik konsentrasi molaritas larutan. Ditemukan pula kondisi tidak terhubungnya level representasi makroskopik, submikroskopik, dan simbolik pada calon guru. Cakupan konsep berkenaan denagn komponen larutan, konsentrasi, serta sifat asam basa pada larutan berair sering diajarkan hanya sebagai hafalan dan perhitungan matematis, tanpa memperhatikan aspek submikroskopik pada jenjang level sekolah. Dengan demikian, hasil analisis ini menunjukkan pentingnya untuk dilakukan perbaikan dalam proses belajar dan mengajarkan kimia bagi calon guru agar tidak terjadi miskonsepsi lanjutan pada siswa dalam memahami konten kimia di masa mendatang.

\section{DAFTAR PUSTAKA}

Arends, R. I. 2012. Learning to teach. New York: McGraw-Hil.

Çetingül, P. I., \& Geban, O. 2005. Understanding of Acid-Base Concept by Using Conceptual Change Approach. Hacettepe Üniversitesi Journal of Education, 29: 6974.

Chaiyapha, P., Chayajarus, K., \& Chairam, S. 2011. Investigation of High School Students' Understanding of Acid-Base Chemistry Based on Jigsaw Method. In Pure and Applied Chemistry International Conference, 139-142.

Chandrasegaran, A. L., Treagust, D. F., \& Mocerino, M. 2007. The Development of A TwoTier Multiple-Choice Diagnostic Instrument for Evaluating Secondary School Students' Ability to Describe and Explain Chemical Reactions Using Multiple Levels of Represent. Chemistry Education Research and Practice, 8(3): 293-307. 
Chittleborough, G., \& Treagust, D. F. 2007. The Modelling Ability of Non-Major Chemistry Students and Their Understanding of The Sub-Microscopic Level. Chemistry Education Research and Practice, 8(3): 274-292.

Chiu, M. H. 2005. A national survey of student's conceptions of chemistry in Taiwan. Chemical Education International, 6(1): 1-8.

Cohen, L., Manion, L., \& Morrison, K. 2007. Research Methods in Education (Sixth Edit). . New York: Routledge.

Devetak, I., Vogrinc, J., \& Glažar, S. A. 2009. Assessing 16-year-old students' understanding of aqueous solution at submicroscopic level. Research in Science Education, 39(2), 157-179.

Devetak, I., Urbančič, M., Grm, K. S. W., Krnel, D., \& Glažar, S. A. 2004. Submicroscopic representations as a tool for evaluating students' chemical conceptions. Acta Chimica Slovenica, 51(4), 799-814.

Drechsler, K., \& Schmidt, H. 2005. Upper Secondary School Students' Uunderstanding of Model $s$ Used in Chemistry to Define Acids and Bases. Science Education International, 16(1).

Eilks, I., Moellering, J., \& Valanides, N. 2007. Seventh-grade Students' Understanding of Chemical Reactions: Reflections from an Action Research Interview Study". Eurasia Journal of Mathematics, Science \& Technology Education, 3(4): 271-286.

Farida, I. 2012. Interkoneksi Multipel Level Representasi Mahasiswa Calon Guru pada Kesetimbangan dalam Larutan melalui Pembelajaran Berbasis Web. Universitas Pendidikan Indonesia.

Hinton, M. E., \& Nakhleh, M. B. 1999. Students' Microscopic, Macroscopic, and Symbolic Representations of Chemical Reactions. Chem. Educator, 4(5): 158-167.

Johnstone, A. H. 2000a. Chemical Education Research: Where from Here? Proceeding University Chemistry Education, 4(1): 34-38.

Johnstone, A. H. 2000b. Teaching of Chemistry - Logical Or Psychological? Chemistry Education: Research and Practice In Europe, 1(1): 9-15.

Krause, S., \& Tasooji, A. 2007. Diagnosing Students' Misconceptions on Solubility and Saturation for Understanding of Phase Diagrams. American Society for Engineering Education.

Lee, K. W. L. 1999. A Comparison of University Lecturers' and Pre-Service Teachers' Understanding of A Chemical Reaction at The Particulate Level. Journal of Chemical Education, 76(7): 1008-1012.

Lin, J. W., Chiu, M. H., \& Liang, J. C. 2004. Exploring Mental Models and Causes of Students' Misconceptions in Acids and Bases. NARST 2004, 1-12.

Metin, M. 2011. Effects Of Teaching Material Based On 5E Model Removed Pre-Service Teachers' Misconceptions About Acids-Bases. Bulgarian Journal of Science and Education Policy (BJSEP), 5(2): 274-302.

Muchtar, Z., \& Harizal, H. 2012. Analyzing of Students' Misconceptions on Acid-Base 
Chemistry at Senior High Schools in Medan. Journal of Education and Practice, 3(15): 65-74.

Mulford, D. R., \& Robinson, W. 2002. An Inventory for Alternate Conceptions among FirstSemester General Chemistry Students. Journal of Chemical Education, 79(6): 739744.

Rahayu, I. 2011. Analisis Kesalahan Konsep Reaksi Asam-Basa pada Guru Kimia dan Siswa SMAN RSBI di Kota Malang serta Upaya Perbaikkannya dengan Strategi Konflik Kognitif. Universitas Negeri Malang.

Sanger, M. J., \& Greenbowe, T. J. 1997. Common Student Misconception in Electrochemistry: Galvanic, Electrolytic, and Concentration Cells. Journal of Research in Science Teaching, 4(34): 377-398.

Schmidt, H., \& Chemie, F. 1995. Applying the concept of conjugation to the Bronsted theory of acid- base reactions by senior high school students from Germany. International Journal of Science Education, 17(6): 733-741.

Sheppard, K. 2006. High School Students' Understanding of Titrations and Related AcidBase Phenomena. Chemistry Education Research and Practice, 7(1): 32-45.

Sirhan, G. 2007. Learning Difficulties in Chemistry: An Overview. Journal of Turkish Science Education, 4(2): 1-20.

Smith, K. J., \& Metz, P. A. 1996. Evaluating student understanding of solution chemistry through microscopic representations. Journal of Chemical Education, 73: 233-235.

Talanquer, V. 2011. Macro, Submicro, and Symbolic: The Many Faces Of The Chemistry "Triplet." International Journal of Science Education, 33(2): 179-195.

Tasker, R., \& Dalton, R. 2006. Research Into Practice: Visualisation of The Molecular World Using Animations. Chemistry Education Research and Practice, 7(2): 141-159.

Treagust, D. F., \& Chandrasegaran, C. 2009. The Efficacy of An Alternative Instructional Programme Designed to Enhance Secondary Students' Competence in The Triplet Relatioship. In J. . Gilbert \& D. Treagust (Eds.), Multiple Representation in Chemical Education: Models \& Modelling in Science Education, 151-164.

Tuysuz, M., Ekiz, B., Uzuntiryaki, E., Tarkin, A., \& Kutucu, E. S. 2011. Pre-Service Chemistry Teachers' Understanding of Phase Changes and Dissolution at Macroscopic, Symbolic, and Microscopic Levels. Procedia Social and Behavioral Sciences Elsevier, 15: 452-455.

Waldrip, B., Prain, V., \& Carolan, J. 2006. Learning Junior Secondary Science through Multi-modal representation. Electronic Journal of Science Education, 11(1): 87-107.

Watters, D. J., \& Watters, J. 2006. Student Understanding of $\mathrm{pH}-\mathrm{I}$ don't Know What The Log Actually Is, I Only Know Where The Button Is On My Calculator. Biochemistry And Molecular Biology Education, 34(4): 278-284.

Wu, H., Krajcik, J. S., \& Soloway, E. 2001. Promoting Understanding of Chemical Representations: Students' Use of a Visualization Tool in the Classroom. Journal of Research In Science Teaching, 38(7): 821-842. 